\title{
THE APPLICATION OF RISK ANALYSIS TO THE PROJECT APPRAISAL OF STINGLESS BEE FARMING IN MALAYSIA FOR SUSTAINABILITY
}

\author{
ILMAS ABDUROFI ${ }^{1 *}$, MOHD MANSOR ISMAIL ${ }^{2}$ AND NORMAZ WANA ISMAIL ${ }^{2}$ \\ ${ }^{1}$ Department of Agricultural Socio-Economics, Faculty of Agriculture, Universitas Gadjah Mada, Yogyakarta 55281, \\ Indonesia. ${ }^{2}$ Institute of Agricultural and Food Policy Studies, Univerisiti Putra Malaysia, Selangor 43400, Malaysia.
}

*Corresponding author: ilmas.abdurofi@ugm.ac.id

Submitted final draft: 10 October 2020 Accepted: 1 December 2020

http://doi.org/10.46754/jssm.2021.08.009

\begin{abstract}
Before implementing the massive production of stingless honeybees in order to increase honey yields, the viability and future sustainability of the stingless bees project should be carefully appraised. The objective of this study is therefore to assess the financial projections and simulate the risk factors that may affect future growth projections of stingless bee farming. The study uses capital budgeting techniques and sensitivity analysis scenarios, tax obligation and tax incentives. The findings showed that the stingless bee farming project in Malaysia is financially viable, highly-profitable and can swiftly recover its initial investment. Specifically, the farms on the Peninsular have high projected cash earning capacity, while more efficient farming and less project risks are seen in the Sarawak region. Additionally, if tax obligations are imposed, all indicators of financial appraisal have shown to be still attractive and the results are more lucrative with the application of tax waivers. Furthermore, the project would not be impacted in the change of hive prices and labour costs, indeed the farm is economically sustainable. The main concern should be changes in selling price as these are a considerable drag on the future appraisal of the project.
\end{abstract}

Keywords: Stingless bees farming, capital budgeting analysis, risk analysis.

\section{Introduction}

The most common species of bees in Malaysia are Apis cerana and Apis mellifera. The annual yield from the Apis cerana or local bees is roughly between 5 and $9 \mathrm{~kg}$, while Apis mellifera or the imported bees tend to produce up to 50 $\mathrm{kg}$ per colony in a year. However, the imported species is prone to pests and disease (Ismail \& Radam, 2010). After declining production in 2010, the quantity of honey exported was dramatically decreased from about 10.94 million tonnes (Mt) in 2011 and continued to decline gradually until 2017, although there was an increase in the amount of honey exported in 2015 (Figure 1). This study assumes that domestic honey resources in Malaysia may not meet the existing demand and local beekeepers have low yields. The participation of new beekeepers should be improved to increase honey yields. Hence, the development of new products or the introduction of new bee species will help to increase the production of local honey and attract more members of society to get involved in bee farming. The alternative to the local honey bee may be as the Trigona species of Stingless bees (Ismail, 2014).

The introduction of stingless bees for sustaining human livelihoods in Malaysia is a relatively new concept. However, in Malaysia the emphasis of most farmers is only on the production of honey and not its medical benefits or alternative uses (Jalil \& Roubik, 2016). Indeed, many studies have indicated that honey has a high potential as a product for health purposes, specifically, the stingless honeybees have similar alternative medicine uses. The Department of Agriculture, Agriculture and Agro-based Industry Ministry (2016) stated that the stingless honeybees may be a national super food due to its benefits to human health and physiology.

A high interest in rearing Malaysian stingless bees has emerged among the Malay population in the countryside (Resnick, 2014). The honey produced by stingless bees is slightly more expensive, due to high investment required to 


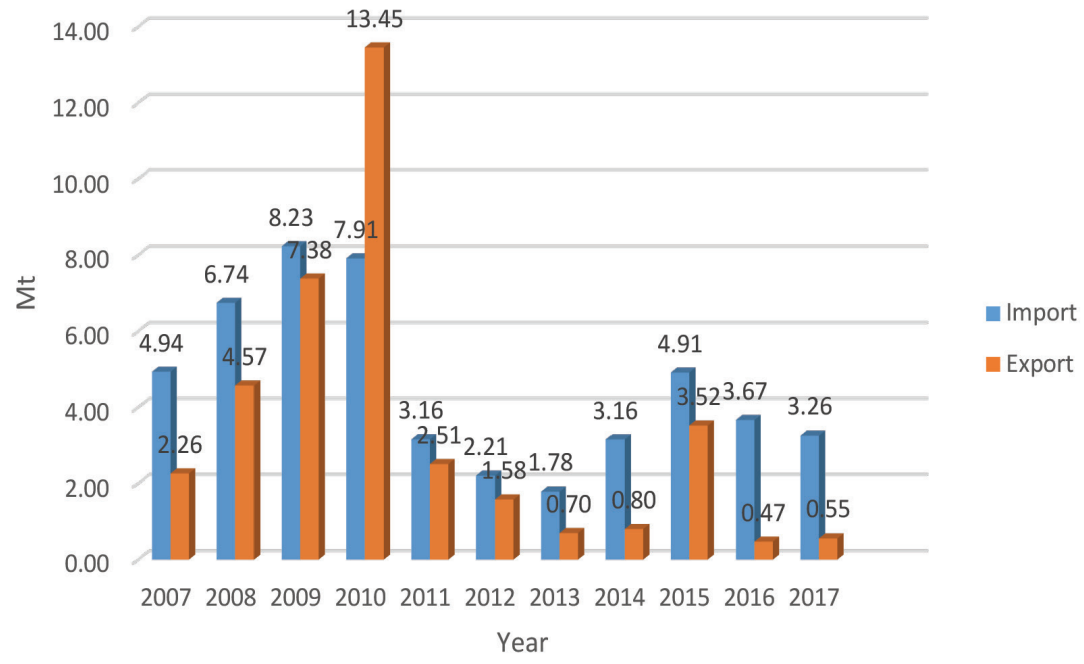

Figure 1: Quantity of honey export-import in Malaysia Source: United Nations Comtrade (2018)

set up the hives. It is about 20 times more costly than the honey produced by other bees (Kumar et al., 2011). Therefore, the selling price of the stingless honeybees honey at the consumer's level is more expensive than common honey.

Then, the honey production per hive of stingless bee is slightly less than other common bees. Moreover, the fundamental aspects of stingless bees farming in post-harvest management and downstream processing remain untouched.

As a longer-term objective, the project feasibility and risk analysis for stingless bees farming needs to be investigated to obtain good information in farm management before suggesting massive commercialisation.

If the project of stingless bees farming is financially feasible and highly sustainable from any risks, this implies to enlist the huge number of new beekeepers to involve inside the industry, would increase the yield of stingless honeybees and cover up the domestic demand of honey (Ismail, 2014).

\section{Literature Review}

In this study, the analysis of project appraisal provides a mutual understanding about the firm's feasibility, profitability, risk and return in the scope of private project evaluation by using capital budgeting technique. Capital budgeting plays a pivotal role in any organisation's financial management strategy. Gitman (2007) defines it as the process of evaluating and selecting long term investments that are consistent with the business's goal of maximising owner's wealth. Capital budgeting techniques are defined as the methods and techniques used to evaluate and select an investment project. It helps managers to select projects with the highest profits at an acceptable risk (Verbeeten, 2006).

Another theory elucidates that capital budgeting is generally used as an essential management tool to assist firms in evaluating their business performance and motivating people (Waal et al., 2011). Empirical studies show that budget is particularly important for a company's plan and control that is widely considered by any organisations (Abdel \& Luther, 2006; Uyar, 2009; Libby \& Lindsay, 2010; Uyar \& Bilgin, 2011).

One of the predominant steps in budget preparation is the use of development analysis in capital budgeting technique. Capital budgeting technique is considered as a process in longterm investment of making planning decisions 


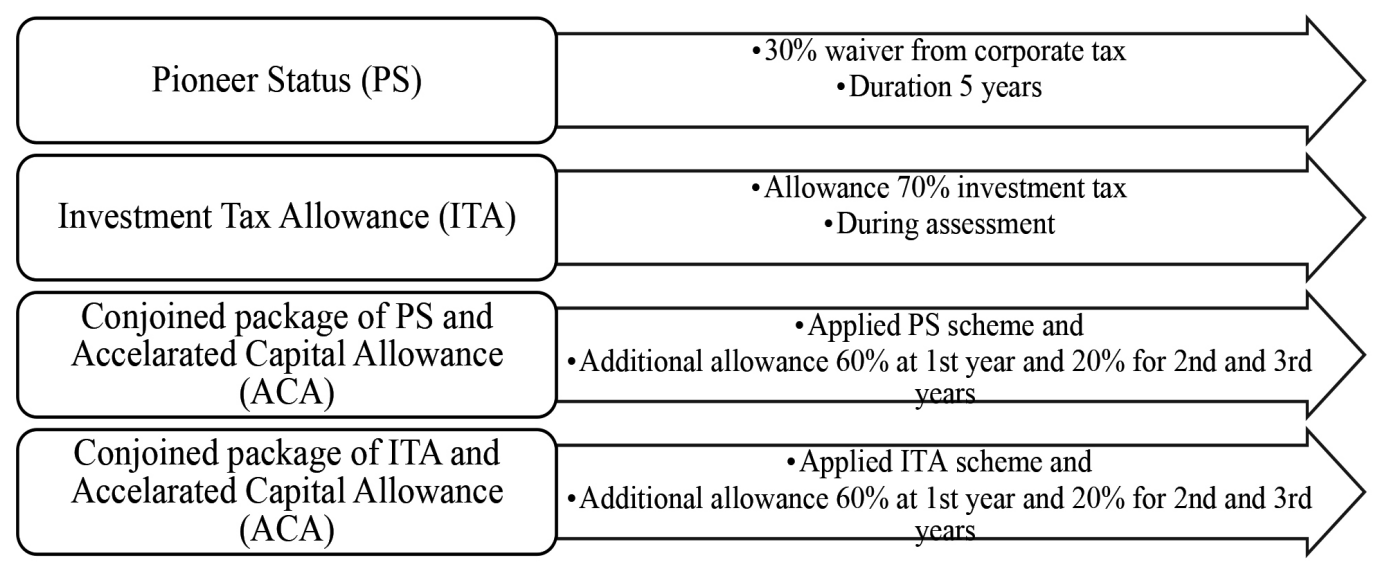

Figure 2: Tax incentive schemes

Source: The Malaysian Industrial Development Authority (2006)

and analysis of opportunities in assets to produce profit during project appraisal (Peterson \& Fabozzi, 2002).

Along with the fundamental assessment of capital budgeting analysis, a calculation of government tax and tax incentives had also been undertaken in the study. According to the Malaysian Industrial Development Authority (2006), enterprises or firms that paid up capital of RM 2.5 million charged tax obligation from $18 \%$ to $25 \%$. However, the government introduced several tax policies to promote investment from any potential sectors such as manufacturing, tourism, environmental activities and agriculture (Figure 2).

The predominant incentive for the agricultural sector is generally offered in Pioneer Status (PS) and Invesment Tax Allowance (ITA) schemes. A Pioneer Status usually awarded is in conjunction with a partial exemption of a company's income tax. This incentive offers a $30 \%$ tax waiver on the company's corporate tax for five years.

Meanwhile, an Investment Tax Allowance is an alternative to the Pioneer Status which grants agriculture firms the right to offset the allowance against $70 \%$ of the investment tax in the year of assessment.

\section{Materials and Methods}

The study focuses on primary data from administering questionnaires and via face-toface interviews with beekeepers in Malaysia. The sources of data collected includes basic financial data such as input-output costs, initial investment and income statement from farm production reports. An expert/judgemental sampling was initially used as a sampling method and the targeted respondents were specifically categorised by several Stingless bee' experts in Malaysia. Thus, the study used 124 stingless beekeepers as a sample size with the average beekeeper having at least 2 acres of land for beekeeping.

The data analysis in this study applies the indicators of capital budgeting techniques as Net Present Value (NPV), Internal Rate of Return (IRR), Profitability Index (PI), and Payback Period. The discount rate is imposed to determine a time value of money to the cost of capital as $10 \%$ during the project assessment. Along with fundamental assessment of financial appraisal, the adoption of tax obligation, tax incentives and sensitivity analysis in the financial projection was also applied to measure the longterm sustainability of the project to face any risks. The financial indicators are shown in the mathematical expressions. 
1 Net Present Value (NPV) is known as the discounted cash flow technique. NPV is related to the increase of shareholder's wealth when a project is undertaken. Sayed et al. (2013) explained that Net Present Value is the most frequently used technique to assess a company decision-making criteria. NPV describes the amount of cash that firms earn in a project. A negative NPV outcome shows that the cost surpasses the benefit, and the project is not economically viable. The NPV determines the amount of wealth and can predict future investment over the project's duration. However, the NPV does not describe the actual profitability of an initial investment. The use of cash flows in NPV calculations is crucial in determining the actual cash money that has been invested in a proposed project (Brigham, 2007). The following formula illustrates this as:

$$
\begin{gathered}
W=\frac{A_{1}}{(1+K)^{1}}+\frac{A_{2}}{(1+K)^{2}}+\cdots+\frac{A_{n}}{(1+K)^{n}}-C \\
N P V \sum_{t=1}^{n} \frac{A_{1}}{(1+K)^{1}}-C \\
\text { Or } \\
N P V \sum_{t=1}^{n}\left(C F_{t} \mathrm{X} P V I F_{k, t}\right)-C F_{0}
\end{gathered}
$$

Wherein,

$\mathrm{W}=\mathrm{NPV}$

$A_{1}, A_{2} \ldots=$ The stream of benefits

$\mathrm{C}=$ Cost

$\mathrm{t}=$ Time

$\mathrm{K}=$ Discout rate

$\mathrm{CF}_{\mathrm{t}}=$ Cash flow

PVIF $=$ Present value

2 Internal Rate of Return (IRR) is the discount rate when the net present value of the project equals to zero. Internal rate return
(IRR) is one of the commonly employed discount rate in evaluation and demonstrates the profitability of a single project. Its value is very clear and apparent for investors to digest. A project's IRR should be compared with the company's cost of capital or hurdle rate. The hurdle rate refers to the rate that the project must surpass to create positive shareholder wealth. Normally, if the IRR value is positive and higher than the discount rate, it shows that the project is acceptable (Mackevicius \& Tomasevic, 2010). Mathematically, IRR can be determined by the following equations:

$$
\begin{gathered}
C_{0}=\frac{C_{1}}{(1+r)^{1}}+\frac{C_{2}}{(1+r)^{2}}+\frac{C_{3}}{(1+r)^{3}}+\cdots+\frac{C_{n}}{(1+r)^{n}} \\
C_{0}=\sum_{t=1}^{n} \frac{C_{t}}{(1+r)^{t}} \\
I R R=\sum_{t=1}^{n} \frac{C_{t}}{(1+r)^{t}}-C_{0}=0
\end{gathered}
$$


Wherein,

$\mathrm{r}=$ Discount rate

$\mathrm{C}=$ Cost

$\mathrm{t}=$ Time

$\mathrm{C}_{0}=$ Initial investment

$\mathrm{C}_{\mathrm{t}}=$ Cash inflow at $\mathrm{t}$ period

3 Profitability Index (PI) or Benefit Cost Ratio(BCR). The profitability index is related to the value of a project's cash flow divided by the cost. The Benefit Cost Ratio (BCR) indicates the ratio of the present value of cost. PI describes the potential profit from the money invested. PI evaluates the investment's profitability and measures the efficiency of a project investment. If the result of PI is above 1 , it indicates that a proposed project is considered to be lucrative. The result will be a breakeven without having any profit or loss on investment if the PI's outcome equals 1 (Satyasai, 2009). The equation is illustrated as follows:

$$
\begin{gathered}
P I=\frac{P V\left(C_{\mathrm{t}}\right)}{C_{0}} \\
P I=\sum_{t=1}^{n} \frac{C_{t}}{(1+K)^{t}}: C_{0}
\end{gathered}
$$

Wherein,

PI $=$ Profitability index

$\mathrm{PV}=$ Present value

$\mathrm{C}_{0}=$ Initial investment

$\mathrm{C}_{\mathrm{t}}=$ Cash inflow at $\mathrm{t}$ period

PV $\left(C_{t}\right)=$ Present value of future cash flows

$\mathrm{C}_{0}=$ Initial investment

$\mathrm{C}=$ Cost

$\mathrm{t}=$ Time

4 Payback Period - The payback period illustrates the number of years required to recover the initial investment. Payback period is often used to predict the risks that are generally encountered to a project, which has a cash flow only in the distant future. Just like with an NPV, the payback period does not measure project profitability or solely stress on the capital recovery of investment. A better project will be considered if it has a greater liquidity and shows shorter payback period. The role of payback is very important to decide the acceptability of an investment project and to determine how fast it needs to recover the cash used to finance the project (Bordman et al., 2006). Payback period can be calculated using the following equation:

$$
P B P=\frac{C_{0}}{C F_{t}}
$$

Wherein,

$\mathrm{PBP}=$ Payback period

$\mathrm{C}_{0}=$ Initial investment

$\mathrm{CF}_{\mathrm{t}}=$ Periodic cash flow

\section{Results and discussion}

The result in Table 1 presented the analysis of capital budgeting techniques of stingless bees farming in Malaysia. The aim of this analysis is to assess the future projection in the long run decision making and appraise whether the project has a potential viability or not. The predominant indicators of capital budgeting techniques are Net Present Value (NPV), Internal Rate of Return (IRR), Profitability Index (PI) and Payback Period (PBP). Based on Table 4.8, the value of Net Present Value (NPV) of stingless bees farming in Malaysia showed positive sign as RM 182,411 , meaning the time value of money or benefit during the project appraisal is considered higher than its present value from the initial asset. In this circumstance, the farm generates a profit, and the project is financially viable. Next, financial indicators; Internal Rate of Return (IRR) was 57\%, it may be assumed that the feasibility of the project is apparent, because $57 \%$ of the IRR is greater than the discount rate used which stands at $10 \%$, which also indicates that the project would be highly resistant to any financial distortion and reduce risk factors inherent in the projection. 
Then, Profitability Index (PI) of the stingless bees farming was 3.55 , solely assumes the viability of the project; that the project may earn RM 2.55 per RM 1 invested in the project; indeed, highly lucrative. Furthermore, the Payback Period (PBP) indicator was 1.73; this indicates that the stingless honeybees' project can recoup its invested capital less than 2 years of operations. Depending on the capital invested, most agricultural projects require more than 5 years to recover their capital investment, hence, this project appears to be an alternatively iablle option to recover the invested capital.

Next, the result of capital budgeting was also presented by regions such as Peninsular Malaysia, Sabah and Sarawak (Table 1). The Net Present Value (NPV) in Peninsular Malaysia seems to have a lot of cash flow during the projection, this indicates the Peninsula farm may generate more earnings than other regions at the value of NPV is RM 381,193. Indeed, this result has a greater value comparing from the study by Abdurofi and Ismail, (2017) that the value of NPV in Peninsular Malaysia is RM 165,008.

On the other hand, Sabah area reported smaller NPV value, this was probably due to lower income. The IRR of Sarawak region was $131 \%$ which is higher than other regions, assuming the project in Sarawak as having less of risk and being more efficient in their usage of resource allocation.

It was followed by Peninsular Malaysia and Sabah at $86 \%$ and $52 \%$ respectively. In terms of Profitability Index (PI), the Sarawak farm received greater value than other regions at 8.08 , indicating any invested project for RM 1 would generate a profit of RM 7.07, this value, however, would attract potential investors with a lucrative project appraisal.

Although, the PI value of Peninsular Malaysia and Sabah was lower than Sarawak, the result still offers high profitability.

The shorter payback period in stingless bees projection in Sarawak area, was estimated that in less than one year the total investment of the project would be covered up. Moreover, the project of Peninsular Malaysia and Sabah requires more than 1.5 years to recoup the payment of invested assets.

To sum up, the four financial indicators of stingless bees project in Malaysia offered an attractive and financially viable for future projection. Thus, the farm would operate as a potential industry for the investment and act as a source of alternative income. While according to Musa et al. (2019), Sarawak supplied almost half of honey production in Malaysia, the result of this study showed that Sarawak region provided a highly efficient farming system.

Figure 3 illustrated the impact of Net Present Value (NPV) in applying corporate tax and government tax incentives scenarios. The corporate tax imposed was $25 \%$ from the total income of the project. Although, the project of stingless bees was categorized as a small or medium farm that it would probably receive tax exemption, the study tried to illustrate as well, the future projection if the corporate tax was applied.

Initially the Malaysian Government offers tax incentives for all companies or farms which are burdened by tax, so as to encourage more investment and boost massive production for any specific industry in the agricultural and

Table 1: Capital budgeting analysis of Stingless Bees Farm

\begin{tabular}{lrrrr}
\hline Financial Indicators & Peninsular Malaysia & \multicolumn{1}{c}{ Sarawak } & \multicolumn{1}{c}{ Sabah } & \multicolumn{1}{c}{ Malaysia } \\
\hline NPV & RM 381,193.00 & RM 196,622.67 & RM 41,656.59 & RM 182,411.30 \\
IRR & $86 \%$ & $131 \%$ & $52 \%$ & $\mathbf{5 7 \%}$ \\
B/C (PI) & 5.27 & 8.08 & 3.26 & $\mathbf{3 . 5 5}$ \\
Payback Period & 1.17 & 0.76 & 1.88 & $\mathbf{1 . 7 3}$ \\
\hline
\end{tabular}


food sectors. Nevertheless, several types of incentive scenarios such as Pioneer Status (PS), Investment Tax Allowance (ITA) and Accelerated Capital Allowance (ACA) that is normally applied in the combination of PS or ITA, the company or farm should solely select one type of tax incentives.

Thus, the illustration of Figure 3 would also provide a proper tax incentive for stingless bees' project in the different situation of tax obligation.

Based on Figure 3, the NPV value with $25 \%$ tax was RM 277,297 in Malaysia. This value is still positive, indicating even with tax obligation, the farm is still viable. Similarly, for all regions, Peninsular Malaysia, Sabah and Sarawak seems financially feasible even with the tax burden. Then, by applying tax incentive scenarios, a combine tax-incentives for stingless bee farming is better than a sole tax-incentive scenario.

By shifting stingless bee farming under ACA on ITA tax- scenario, the project farm viability would improve by RM 333,653 in Malaysia. Thus, stingless beekeepers in Malaysia should explore ACA on ITA tax-incentives scenario in their farming for better viability. Based on the regions, both in Peninsular Malaysia and Sabah recorded high NPV when applying combinations of ACA and ITA.

Thus, it was suggested for those regions to select ACA and ITA instead of individual tax incentive while in Sarawak, it is preferable to apply the combination of ACA and PS in order to attain high profitability under tax paying assumption.

Analyses of tax obligation and taxincentives of Internal Rate of Return (IRR) in stingless bees farming were presented in Figure 4. Results showed that after the applied corporate tax was granted, the farm in Malaysia seemed financially viable since $45 \%$ of IRR was still greater than the discount rate at $10 \%$. Similarly, the IRR value among all different regions presented IRR more than $10 \%$ discount rate. It may be concluded that the applied tax burden would not be affected significantly to future projection of IRR.

Moreover, the results also showed that stingless bees farming improved its viability when the tax incentive was applied, while the ACA on ITA provided the most viability with the highest IRR among all regions and Malaysia. Hence, the project should be promoted based on increased streams of expected income.

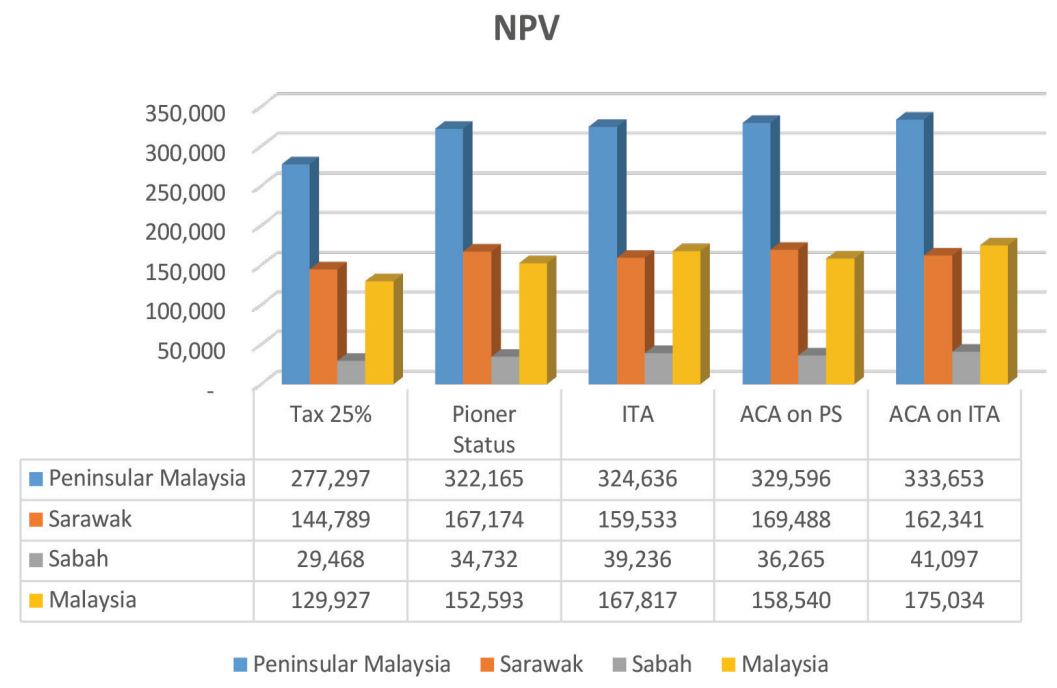

Figure 3: The results of NPV with $25 \%$ tax and tax incentive schemes 


\section{IRR}

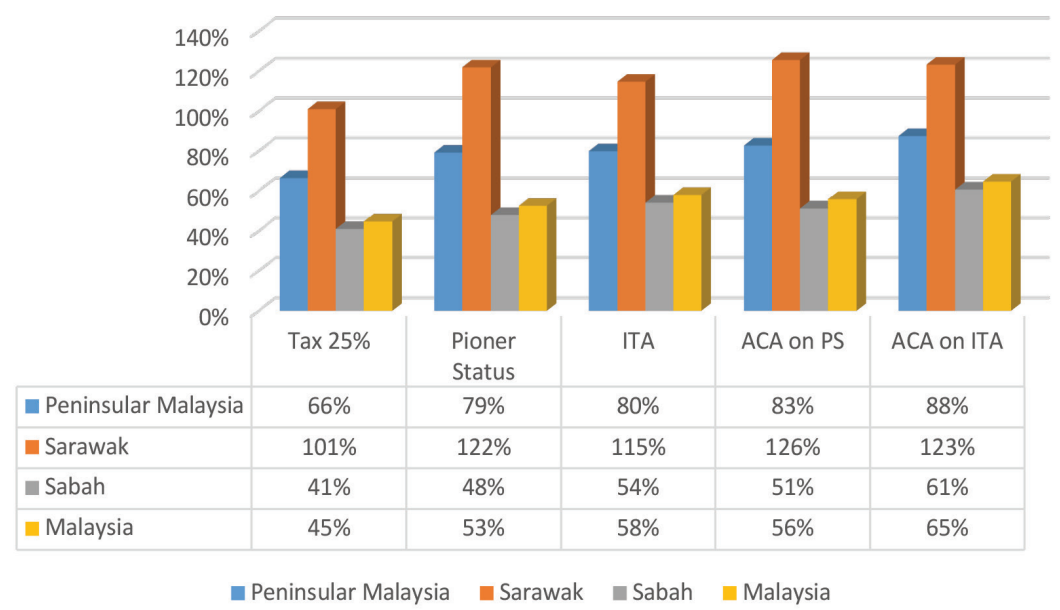

Figure 4: The results of IRR with $25 \%$ tax and tax incentive schemes

Based on the result in Figure 5, it is obvious that irrespective of tax incentives, all the stingless bees' projects were still profitable. The tax incentive projects consistently showed better profitability; the ACA on ITA was the most profitable project with gain of RM 2.45 per RM 1 invested in Malaysia. Similarly, the two regions in Malaysia, Peninsular Malaysia and Sabah were also more appropriate in choosing the ACA on ITA to attain more profit for their investment. Nevertheless, it was crucial to note that the ACA on PS tax incentive was the most viable under Sarawak region, as receiving RM 6.10 for RM 1 invested.

The result of the payback period under tax obligation and tax incentives was presented in Figure 6. The actual value of payback period without tax incentives still showed shorter period of receiving back the amount of invested capital. The payback period for stingless bee project in Malaysia only requires about 2.18 years. Likewise, all regions solely expected

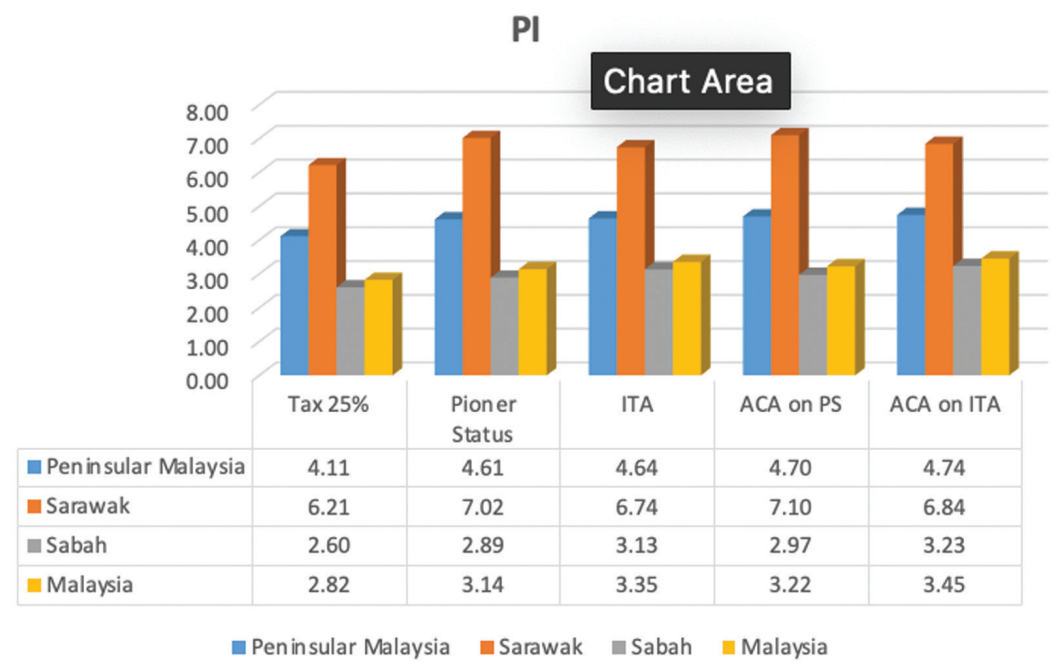

Figure 5: The results of PI with 25\% tax and tax incentive schemes 
their investment to recoup back within less than 3 years under tax burden. Moreover, by applying tax incentive scenarios in the capital budgeting techniques of Payback Period (PBP), all farms had a lower period to recover their investment, while a combine tax-incentives were better than a sole tax-incentive scenario.

However, it was noticeably clear that the combination of ACA on ITA offers attractive schemes for all regions and Malaysia as a whole since the figure of ITA deducted the tax from the asset invested.

\section{Risk Analysis of Stingless Bees Farming in the Project Evaluation}

In order to simulate the changes in key variables due to farm distortion and risk, the role of sensitivity analysis in evaluating project appraisal plays important policy decision. Pannell (1996) defined that the parameter assumption and values for any economic models are indicated in the change and error where the role of sensitivity analysis is widely defined as the investigation of potential changes, errors and effect on the conclusion to be drawn on the existing model. In this study, the change in revenue and costs are considered in evaluating the sensitivity analyses. The analyses were applied by changing the magnitude of honey selling price, hive investment and labor costs; it was simulated based on $-45 \%,-30 \%,-15 \%$, $15 \%, 30 \%$ and $45 \%$ respectively.

The reason for selecting the hive and labour cost in the application of the sensitivity analysis is because those costs were major contributors in the initial investment and variable expenses respectively. The revenue of the stingless bees farming is related to the honey selling price, and hence, the study also tried to simulate the impact of changing the selling price to the income or output of the farm.

Furthermore, the estimation of sensitivity analysis of this study focused on the indicator of Net Present Value (NPV), since NPV is the most frequent analysis of capital budgeting analysis and the result of Net Present Value (NPV) would determine comprehensively the project viability.

The Figure 7 illustrated the result of sensitivity analysis of stingless bees farming in Malaysia. Even after increasing the hive cost by $15 \%, 30 \%$ and $45 \%$, the value of NPV was still positive, indicating the project is still viable. Then, the decrease of hive cost by $45 \%$ would increase the NPV value to RM 203,919. As the line of changing hive cost was slightly flat, it assumes that the impact of changing hive price in the project would not be significantly apparent.

\section{Payback Period}

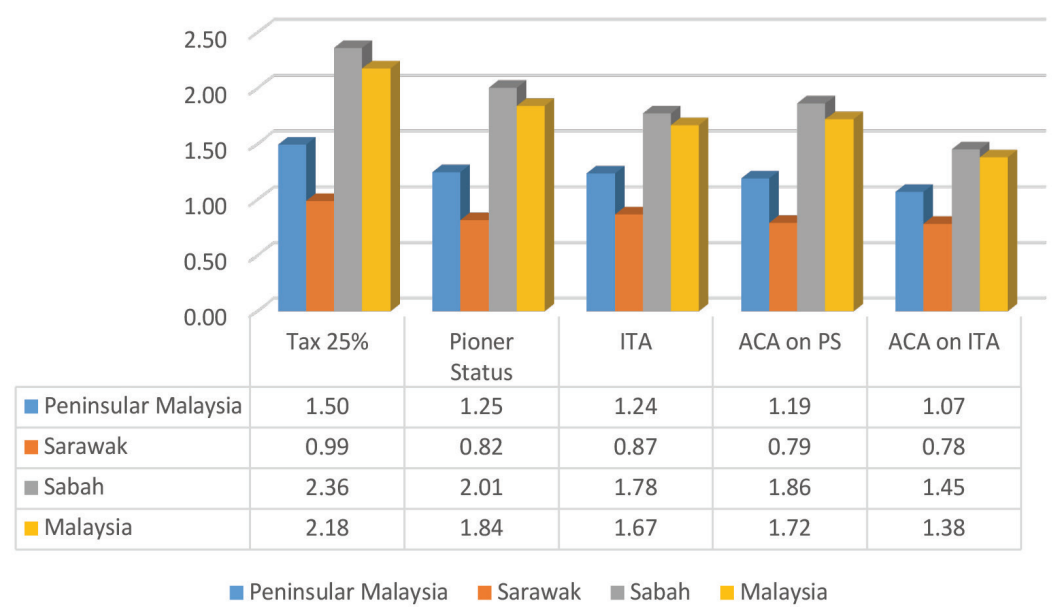

Figure 6: Risk analysis of stingless bees in the project evaluation 
Similarly, the changing of the labour cost would not drastically impact the value of NPV in the stingless bees' project in Malaysia. However, the effect of labour expenses is slightly higher than hive expenditure, since the line of labour cost seemed rather steep, this showed as a decrease of labour expenses by $45 \%$ resulted in an increased of RM 250,128. for Net Present Value.

On the contrary, the line of selling honey price per $\mathrm{kg}$ was obviously the steepest and this would lead to significant changes in the NPV. As a result, by decreasing $45 \%$ of honey price, the NPV generated negative sign, indicating the stingless bees' project is not financially viable or the project must be rejected for further investment.

Then, the Figure 8, 9 and 10, illustrated the sensitivity analysis of stingless bees' project in different regions namely Peninsular Malaysia, Sabah and Sarawak respectively. Similarly, the indicator of capital budgeting technique used the Net Present Value of changing hive investment, labour cost, and local honey price by $-45 \%$, $-30 \%,-15 \%, 15 \%, 30 \%, 45 \%$.

According to the results in Figure 4.12, 4.13 and 4.14 , an increase of hive investment to $45 \%$ would not significantly influence the NPV value for Peninsular Malaysia, Sabah and Sarawak. The value was RM 352,119., RM 38,727. and RM 192,486. respectively. Likewise, the shifting of labour charge still recorded positive NPV for all regions at $45 \%$ increment. Nevertheless, the change of labour cost was slightly more sensitive than hive expenditure since the line of labour cost was steeper the hive expenditure line for all areas.

Contrarily, the slope of selling price of stingless honeybees was the steepest for all regions, This indicates the honey price plays a major concern in impacting the project and clearly identifies whether the project would still generate profit or not. As the outcome from Figure 4.12 , a decrease of selling price by $45 \%$ in Peninsular Malaysia resulted RM 38,776. in NPV, which drastically reduced from the base

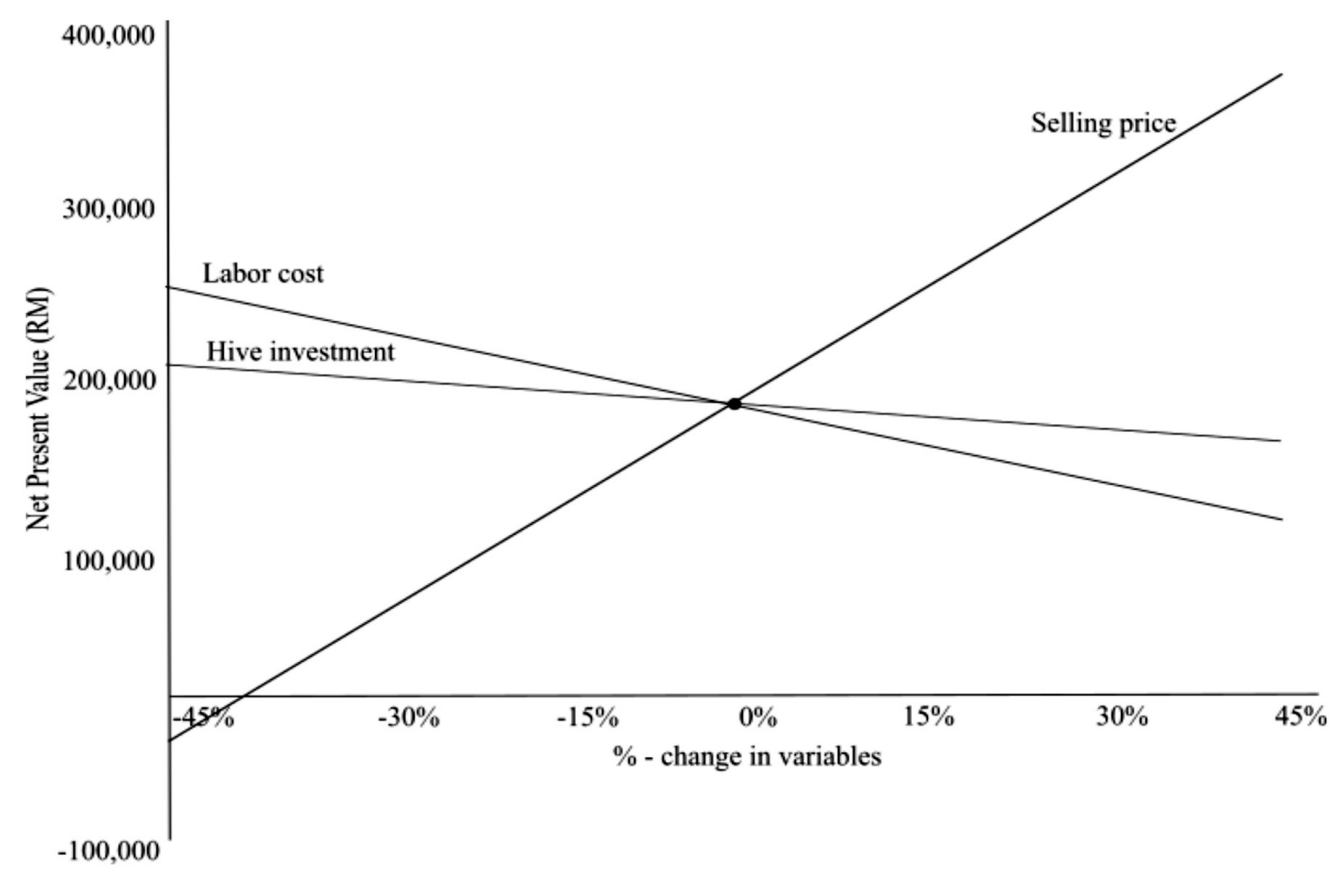

Figure 7: Sensitivity analysis of Stingless Bees Farming in Malaysia 


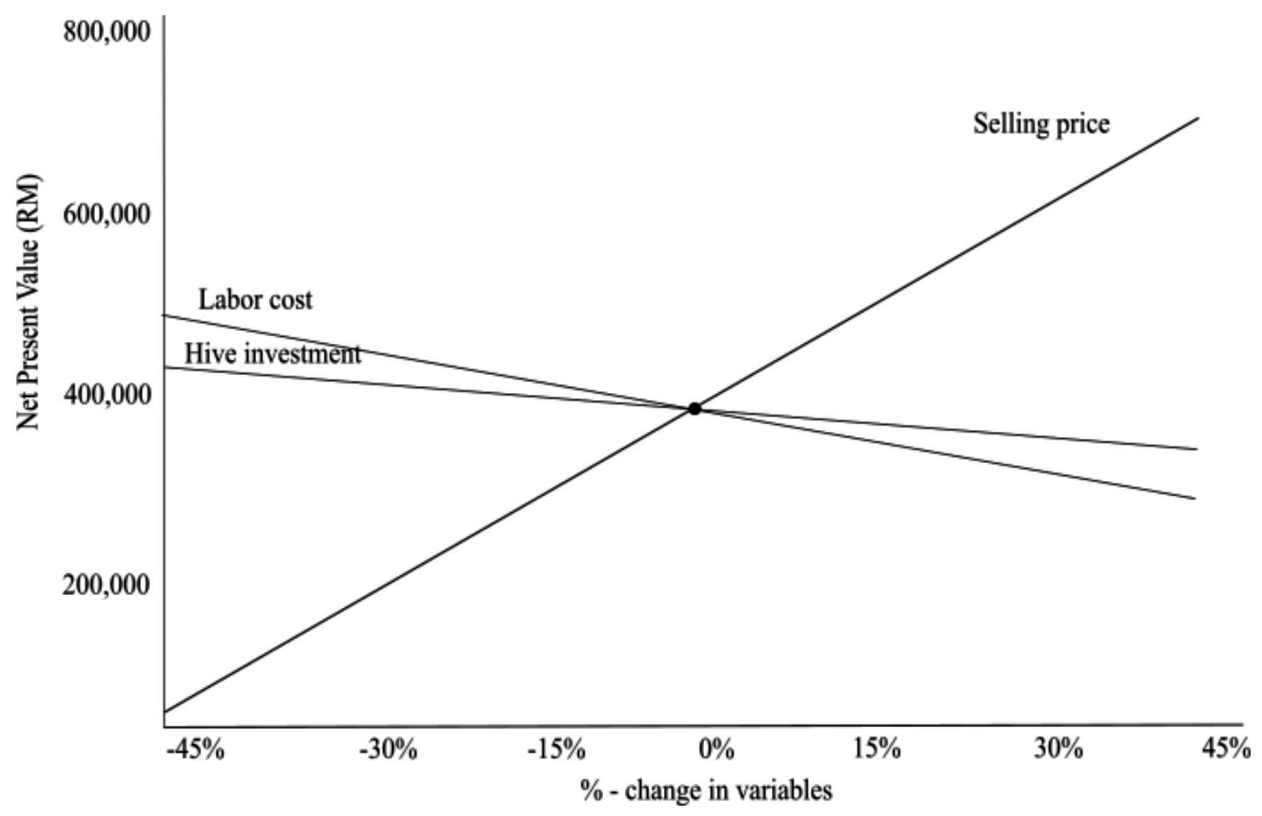

Figure 8: Sensitivity analysis of Stingless Bees Farming in Peninsular Malaysia

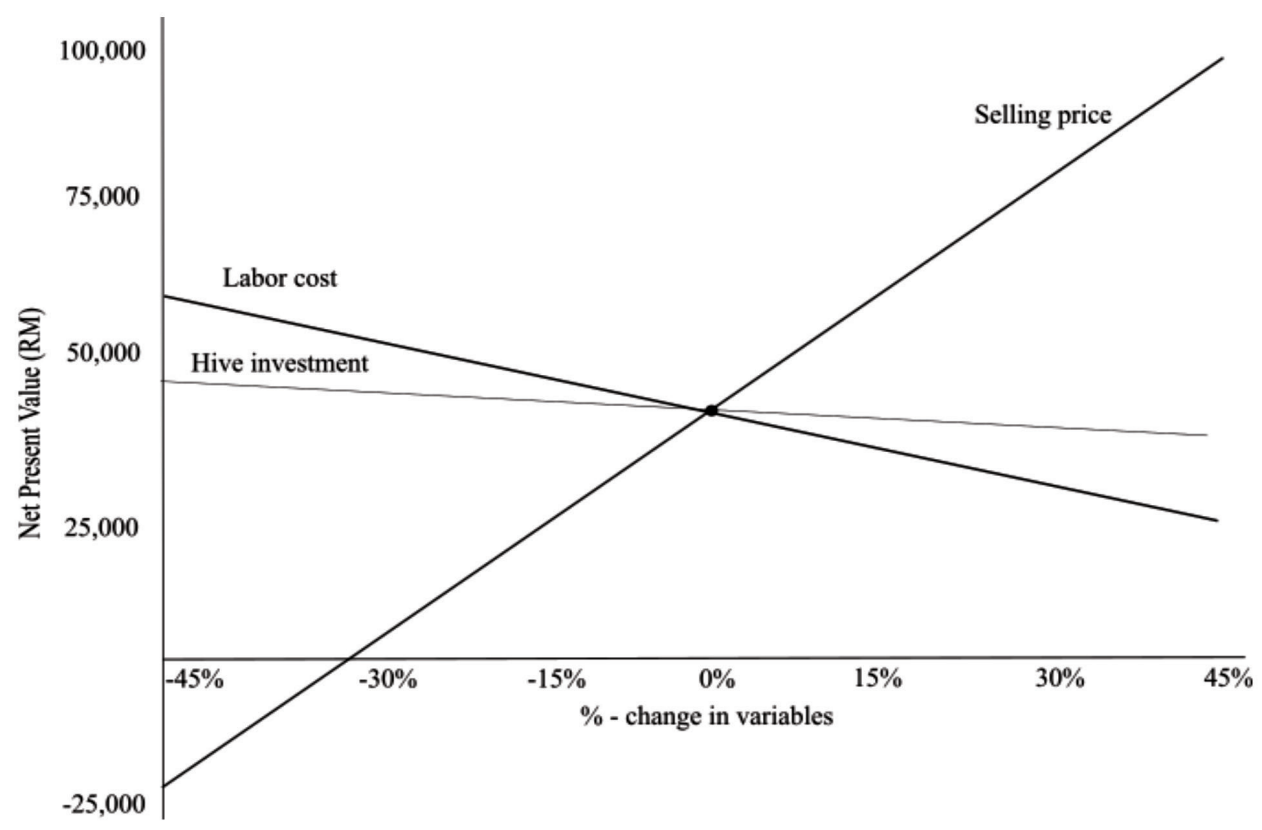

Figure 9: Sensitivity analysis of Stingless Bees Farming in Sabah 


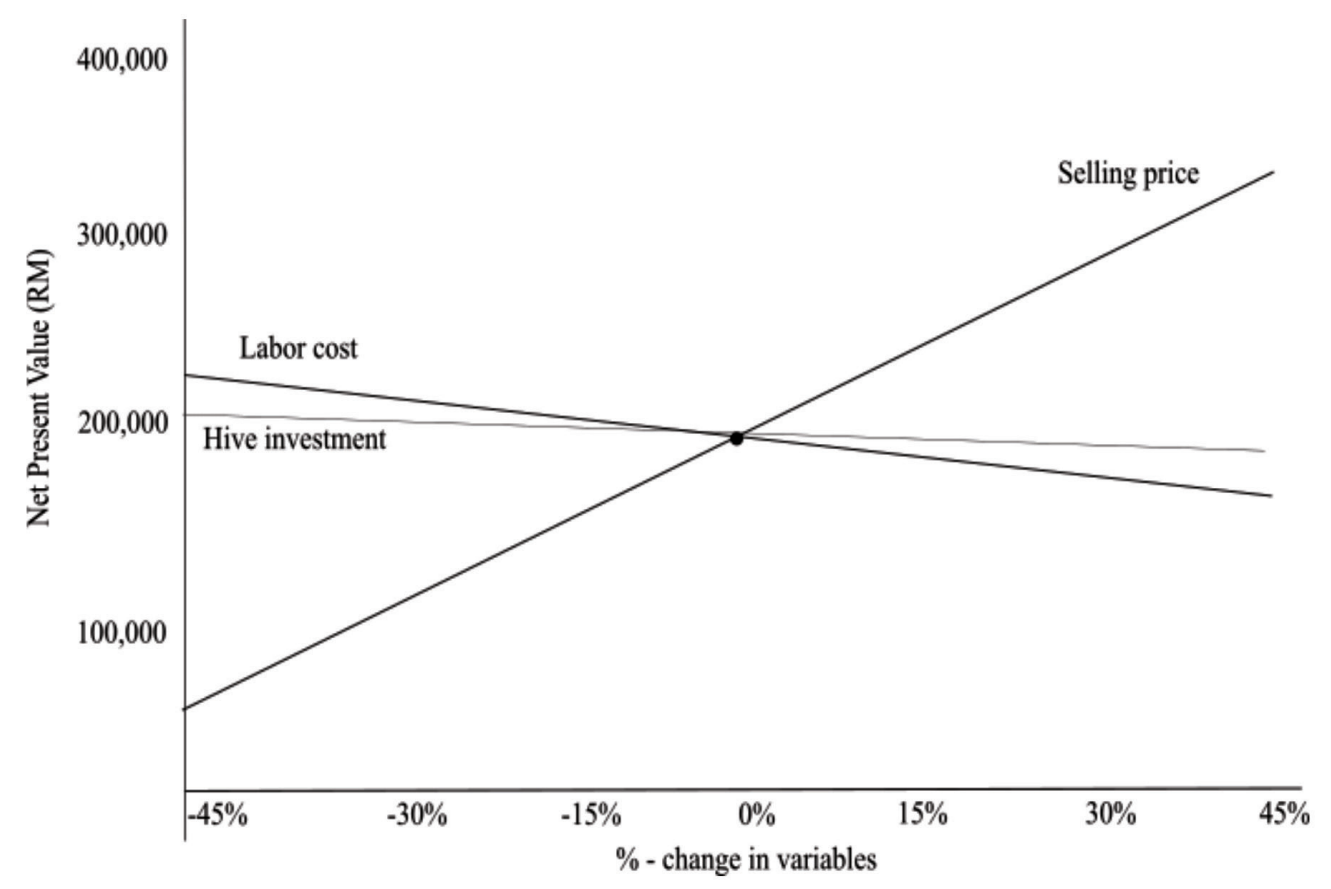

Figure 10: Sensitivity analysis of Stingless Bees Farming in Sarawak

value of RM 381,193. Explicitly, the value of NPV showed negative sign for a drop of local honey price by $45 \%$ in Sabah, - RM 19,749. (Figure 4.13). Furthermore, the Figure 4.14 also showed Sarawak region was affected significantly for decreasing $45 \%$ of selling price in the local market as the NPV value changed from RM 196,622 to RM 55,095.

\section{Conclusion}

In conclusion, the four financial indicators of stingless bees' project in Malaysia were seemingly attractive and financially feasible for future projection. The farm would operate as a potential industry for the investment and act as a source of alternative income. If there were several distortions in the farming system, as paying government tax or increasing the cost of hive and labour, the project is still sustainable and positively viable.

The farm should only beware to the change of selling price at producer level, although a little change still keeps the farm to be lucrative business. Hence, the government should promote stingless bees industry and encourage more stingless beekeepers to get involved in the project. If many beekeepers participate, the domestic production of stingless honeybees would increase and have enough supply to meet the local demand. Furthermore, the Sarawak region showed more efficient farming system, while Peninsular Malaysia has high cash flow operation in the project.

Thus, the study also recommended that the government should focus on massive production of stingless honeybees in Sarawak area and turn Peninsular Malaysia into a main concentration of trading and marketing honey products.

\section{Acknowledgements}

The authors would like to acknowledge and thank the Education Ministry (MOE), Malaysia for funding this research via TRGS Research Grant (No: 5535706). . 


\section{References}

Abdel, K. M., \& Luther, R. (2006). Management accounting practices in the British food and drinks industry. British Food Journal, 108(5), 336-357.

Abdurofi, I., \& Ismail, M. M. (2018). The impact of government incentives on Trigona's project assessment in Peninsular Malaysia. Advances in Intelligent Systems Research (AISR), Atlantis Press, 149.

Bordman, C. M., Walter, J., \& Stephen, E. C. (2006). The role of capital payback period in the theory and application of duration to capital budgeting. Journal Business Finance and Accounting, 9(4), 511-522.

Brigham, E. (2007). Fundamental of financial management. New York: Dryden Press.

Department of Agriculture, Ministry of Agriculture and Agro-Based Industry Malaysia. (2017). September 2017 [online]. Retrieved on $19^{\text {th }}$ September 2018 from https://www.moa.gov.my/en/aktivititerkini-2017

Gitman, L. J. (2007). Principles of managerial finance $\left(11^{\text {th }}\right.$ ed.). San Diego: Pearson International.

Ismail, M. M. (2014). Competitiveness of beekeeping industry in Malaysia. Inaugural Lecture Series. Serdang: Universiti Putra Malaysia Press.

Ismail, M. M., \& Radam, A. (2010). Measuring the effect of Asian financial crisis on the comparative advantage of the food processing industry. International Journal of Economics and Management, 4(2), 279 - 296.

Jalil, A. H., \& Roubik, D. W. (2016). Handbook of meliponiculture, Indo-Malayan stingless bees. Selangor: Akademi Kelulut Malaysia Sdn Bhd.

Kumar, M. S., Singh, A. J. A., \& Alagumuthu, G. (2011). Traditional beekeeping of stingless bee (Trigona $s p$ ) by Kani tribes of Western
Ghats, Tamil Nadu, India. Indian Journal of Traditional Knowledge, 11(2), 342-345.

Libby, T., \& Lindsay, R. M. (2003). Budgeting: An unnecessary evil. CMA Management, 2003, $30-33$.

Malaysian Industrial Development Authority. (2006). Malaysia - Incentives for Investment. [online]. Retrieved on $25^{\text {th }}$ March 2015 from https://www.miti.gov.my/ cms/content

Mackevicius, J., \& Tomasevic, V. (2010). Evaluation of investment projects in case of conflict between the internal rate return and the net present value method. Ekonomika Journal, 89(4), 116-130.

Musa, M., Ismail, M. M., Ismail, W. R., \& Elpawati. (2019). Effectiveness of extension agent services in influencing the adoption of modern hive in sustainable stingless beekeeping. Journal of Sustainability Science and Management, 14(4), 14-24.

Pannell, S. (1996). Homo nullius or where have all the people gone?: Refiguring marine management and conservation approaches. The Australian Journal of Anthropology, 7(1), $21-42$.

Peterson, P. P., \& Fabozzi, F. J. (2002). Capital budgeting: Theory and practice. New York: Wiley.

Resnick, J. A. (2014). A snapshot of meliponiculture in Malaysia, An industry in infancy. Terengganu: Institute of Marine Biotechnology, University of Malaysia Terengganu.

Satyasai, K. J. S. (2009). Application of modified internal rate of return method for watershed evaluation. Agricultural Economic Research Review, 22, 401-406.

Sayed., Nezhadfahim, S. R,. Eghdami, E., Yosefnezhad., \& Maleki, M. (2009). Investigating the procedure of financial factors in successful Companies. Research Journal of Recent Science, 2(3), 44-48. 
Uyar, A. (2009). An evaluation of budgeting approaches: Traditional budgeting, better budgeting, and beyond budgeting. Journal of Academic Studies, 11(42), 113 -130.

Uyar, A., \& Bilgin, N. (2011). Budgeting practices in the Turkish hospitality industry: An exploratory survey in the Antalya region. International Journal of Hospitality Management, 30, 398 -408.

Verbeeten, F. H. M. (2006). Do organizations adopt sophisticated capital budgeting practices to deal with uncertainty in the investment decision? A research note. Management Accounting Research, 17(1), 106-120.

Waal, A., Hermkens, J. M., \& Van De Ven, A. (2011). The evolutionary adoption framework: Explaining the budgeting paradox. Journal of Accounting and Organization Change, 7(4), 316-336. 